\title{
Active porosity in swelling claystone and shales: insight from the Callovo-Oxfordian claystone
}

\author{
Malik Belmokhtar ${ }^{1}$, Pierre Delage ${ }^{I^{*}}$, Siavash Ghabezloo ${ }^{1}$, Nathalie Conil ${ }^{2}$ \\ ${ }^{1}$ Ecole des Ponts ParisTech, UR Navier/CERMES, 6-8 av. B. Pascal, 77455 Marne la Vallée, France \\ ${ }^{2}$ Andra, Bure, France
}

*pierre.delage@enpc.fr; 33685231156 - orcid.org/0000-0002-2101-5522

24 February 2017, 4128 words

\begin{abstract}
In swelling claystones, significant clay-water interactions take place along the faces of the smectites minerals contained in the clay fraction, giving rise to the distinction between free water and adsorbed water. Further insight was recently gained by means of microstructure investigations, showing that the hydration mechanisms of pure or compacted smectites also hold to explain the hydration and swelling behaviour of the Callovo-Oxfordian (COx) claystone, a possible host rock for deep radioactive waste disposal in France. In this rock, the proportion of water molecules adsorbed in intra-platelets pores was recently estimated to around $25 \%$ of the total porosity, with $75 \%$ of the porosity containing free water. Based on these findings, the data of high precision poroelastic measurements conducted in an isotropic compression cell showed that the porosity to account for a proper calculation of the Skempton parameter is not the total porosity, but the $75 \%$ proportion corresponding to free water. This conclusion is believed to be of some interest with respect to the prediction of the rock response around the disposals at great depth, given that hydromechanical numerical simulations are often carried out within the framework of poroelasticity.
\end{abstract}

Keywords: Radioactive waste disposal, claystone, microstructure, poroelasticity, adsorbed water, swelling, smectite 


\section{Introduction}

The status of water in clayey soils and clay rocks (also called mudstones, claystones or shales) is known to be governed by the interactions between the water molecules and the active clay minerals contained in the clay fraction. A distinction is often made between free and adsorbed water, without however any detailed definition about the difference between these two physical states of water. Free water is supposed to have the properties of bulk water (density, viscosity, thermal expansion coefficient,...), whereas this should not necessarily be true for adsorbed water, the state of which is often described in the literature as being governed by clay water interactions governed by the double-layer theory (e.g. Bolt 1956, Sridharan and Jayadeva 1984, Baldi et al. 1988, Schanz and Tripathy 2009).

In the theory of poroelasticity, the state of water is by definition that of bulk water, and poroelastic calculations are made by adopting the physical properties of bulk water, like the unit mass $\rho_{w}\left(1 \mathrm{Mg} / \mathrm{m}^{3}\right)$ and the compression modulus $K_{w}$ (2,24 GPa, Spang, 2002). Similarly, the thermal expansion coefficient $\alpha_{w}$ and its changes with temperature adopted in thermoporoelastic calculations are that of bulk water (e.g. Baldi et al. 1988). The question as to whether the value of porosity to adopt in poroelastic calculations is the total porosity or that corresponding only to the fraction of free water then arises in clay soils and rocks.

This work is based on the data of two recent works carried out in the same research group about, on the one hand, the status of water in swelling claystones or shales (Menaceur et al., 2016) and, on the other hand, the poroelastic behaviour of the Callovo-Oxfordian (COx) claystone (Belmokhtar et al. 2016). The COx claystone is considered in France as a possible host rock for the long-term disposal of high activity exothermic radioactive wastes at great depth. Further insights into the poroelastic response of the COx claystone is necessary so as to better predict the thermo-hydro-mechanical response around the galleries during the thermal phase of the repository (see Gens et al. 2007). 


\section{Background}

Swelling clays and shales have a given proportion of smectite materials in their clay fraction. Clay water interactions in smectites have been investigated in details for a long time by clay mineralogists by using X-Ray diffraction techniques (including Mooney et al. (1952); Méring and Glaeser 1954; Norrish 1954; Bérend et al. 1995; Cases et al. 1997, Tessier et al. (1998); Saiyouri et al. (2004); Ferrage et al. 2005, 2007). Although it is seldom considered in geomechanics, it is now well accepted that the adsorption of water molecules along the surface of smectite minerals during hydration from a dry state is governed by the successive adsorption of 1,2 and then 3 molecules of water (also called $1 \mathrm{~W}, 2 \mathrm{~W}$ and $3 \mathrm{~W}$ hydration states, respectively). The hydration of smectites starts from an initial inter-basal spacing of $9.6 \AA$ at dry state, followed by inter-basal spacings of $12.6,15.6$ and $18.6 \AA$ for $1 \mathrm{~W}, 2 \mathrm{~W}$ and $3 \mathrm{~W}$ hydrations, respectively. The number of water layers is controlled by the value of the water potential (or suction) imposed to the smectite specimen, with approximately 1 layer at suction of various hundreds of $\mathrm{MPa}$ (12.6 $\AA$ basal spacing), 2 layers at suction of various tens of $\mathrm{MPa}$ (15.6 ̊̊ basal spacing) and 3 layers below $10 \mathrm{MPa}$ (18.6 ̊̊ basal spacing). It has also recently been demonstrated that these conclusions, drawn from investigating pure montmorillonites with various cations (e.g. Ferrage et al. 2007) and compacted montmorillonites (Saiyouri et al. 2000, 2004), also hold along the faces of the smectite minerals contained in the mixed layer illitesmectite minerals of the clay matrix of the COx claystone (Menaceur et al., 2016). This observation allowed to further define the status of water in the COx claystone based on mercury intrusion porosimetry (MIP) measurements. As commented in more details in Menaceur et al. (2016), the porosity intruded by mercury at maximum pressure of $227.5 \mathrm{MPa}$ (equivalent entrance diameter of $5.5 \mathrm{~nm}$ ) approximately corresponds to the volume of free water contained within the inter-platelets pores, whereas smaller pores (called the infra-porosity) corresponds to the intra-platelets planar voids inside the clay platelets within a clay matrix that constitutes 
around $50 \%$ of the COx claystone. Menaceur et al. (2016) showed that the thickness of these intra-platelets planar voids was governed by the smectite hydration mechanisms described above. Another important conclusion drawn by Menaceur et al. (2016) is that the number of molecules adsorbed in the COx claystone at natural state is equal to 2 (2W hydration).

Following previous works that proposed for the COx claystone values of the Biot $b$ parameter along a rather large range (between 0.4 and 0.9, Vincké et al. 1998, Escoffier 2002, Bemer et al. 2004, Escoffier et al. 2005, Homand et al. 2004), a better knowledge of the poroelastic properties of the COx claystone has recently been gained by Belmokhtar et al. (2016), through a detailed determination of the various poroelastic parameters within a transverse isotropic framework (Biot parameters $b_{1}$ and $b_{2}$, Biot modulus $H$, compression modulus of the solid phase $K_{s}$ ). Recent contributions on this topic also include Noiret et al. (2010) on the Tournemire claystone, Yuan at al. (2017) on the COx claystone and Keller (2017) on the Opalinus clay. In a purpose of simplicity and to help in numerical calculations that are most often conducted within an isotropic equivalent framework (Gens et al. 2007), equivalent isotropic values have also been proposed. It was shown in Belmokhtar et al. (2016) that the equivalent isotropic value of the Biot parameter $b$ of the COx claystone was larger than 0.77.

It was found interesting to bring together the considerations of these two works to gain further understanding about the exact value of the porosity involved in poroelastic calculations in the case of swelling clay rocks, in which a given proportion of pore water is adsorbed and does not have the physical properties of bulk water.

\section{Materials and methods}

\subsection{The Callovo-Oxfordian claystone}

The Callovo-Oxfordian claystone is a sedimentary rock deposited 155 million years ago over a layer of Dogger limestone in a $150 \mathrm{~m}$ thick layer covered by a layer of Oxfordian 
limestone. The COx claystone has a very low permeability in the order of $10^{-20} \mathrm{~m}^{2}$ (see Escoffier 2005, Homand et al. 2004, Escoffier et al. 2005, Mohajerani et al. 2011, Menaceur et al. 2015a), a high adsorption capacity for radionuclides and a low diffusion coefficient delaying solute transfer. For all these reasons, it has been considered as a potential host rock to store high activity radioactive waste at great depth in France.

The clay and carbonate contents of the COx claystone vary with depth (Gaucher et al., 2004). The total porosity of the COx claystone is estimated between $14 \%$ in carbonated levels and $19.5 \%$ in more argillaceous levels, like at $490 \mathrm{~m}$ depth (Yven et al., 2007). The microstructure of the COx claystone has been investigated in more details by Robinet et al. (2015) and Davy et al. (2015) by using advanced investigation techniques, like for instance the Focussed Ion Beam techniques (see also Keller et al. 2011 on the Opalinus Clay). At the middle of the COx layer (depth $490 \mathrm{~m}$ ) where the Bure Underground Research Laboratory (URL) managed by Andra (the French agency for the management of radioactive waste) is located, the COx claystone is characterised by a clay matrix (45-50\%) in which are embedded $20-30 \%$ carbonates, $20-30 \%$ quartz and a small fraction of feldspar. The clay fraction is composed of $10-24 \%$ interstratified illite/smectite layers, $17-21 \%$ illite, 3-5\% kaolinite, 2-3\% chlorite (Gaucher et al., 2004). The smectite fraction is responsible for the swelling capacity (e.g. Mohajerani et al. 2011) and excellent self-sealing capacity of the COx claystone (e.g. Davy et al. 2007; Zhang and Rothfuchs 2008; Menaceur et al. 2015a).

The in-situ stress condition at the level of the URL $(490 \mathrm{~m})$ has been investigated in details by Wileveau et al. (2007), evidencing an anisotropic stress state with a lithostatic vertical stress $\left(\sigma_{v}=12.7 \mathrm{MPa}\right)$, a minor horizontal total stress $\sigma_{h}=12.4 \mathrm{MPa}$ close to $\sigma_{v}$, and a major horizontal total stress $\sigma_{H}=12.7-14.8 \mathrm{MPa}$. The measurement of pore water pressure provided a hydrostatic value of $p_{w}=4.9 \mathrm{MPa}$. 
The specimen tested (EST31912c) was extracted at a depth of $490 \mathrm{~m}$ in the Bure URL. It was carefully diamond cored with a diameter of $38 \mathrm{~mm}$ from a $80 \mathrm{~mm}$ diameter core in the direction perpendicular to the bedding plane, and cut at the required length of $10 \mathrm{~mm}$ with a diamond saw. The water content $(w=7.45 \%)$ was obtained by weighing before and after ovendrying during $48 \mathrm{~h}$ at $105^{\circ} \mathrm{C}$. The porosity $(17.6 \%)$ was determined from volume measurements by hydrostatic weighing, providing a saturation degree of $94.2 \%$. A suction of $19.7 \mathrm{MPa}$ was measured by using a dew point potentiometer (WP4C, Decagon Devices). This high degree of saturation indicates that little evaporation occurred after coring and corresponds to a good quality sample.

\section{The status of water in the COx claystone}

Figure 1 shows the pore size distribution (PSD) curve of a sample of the COx claystone extracted at a depth of $490 \mathrm{~m}$ (Delage et al., 2014). As explained in more details in Menaceur et al. (2016), dehydration was made by freeze-drying after plunging small COx specimens in slush nitrogen at $-210^{\circ} \mathrm{C}$, following Delage et al. (2006). The PSD curve shows that the porosity of the COx claystone detected by MIP is quite well defined around an average entrance diameter of $32 \mathrm{~nm}$, with a mercury intruded porosity of 0.130 compared to a total porosity of 0.174 , defining an infra-porosity (not intruded by mercury at maximum pressure) of 0.034 . As detailed in Menaceur et al., (2016), this average diameter is characterising the inter-platelets porosity. Based on a simplified brick model of the microstructure proposed by Yven et al. (2007), the average $32 \mathrm{~nm}$ diameter can be related to an average thickness of $32 \mathrm{~nm}$ of the platelets, providing an average number of layers of 21 with a $2 \mathrm{~W}$ hydration in a sample in which a suction of $21 \mathrm{MPa}$ was measured prior to dehydration.

Note that Menaceur et al., (2016) also discusse in more detail the effect of oven-drying the specimens during $48 \mathrm{~h}$ at $105^{\circ} \mathrm{C}$. It is known that the expulsion of all the adsorbed water molecules occurs in pure smectites at around $450{ }^{\circ} \mathrm{C}$ (e.g. Caillère et al. 1982; Cases et al. 1992; 
Berend et al. 1995). Ferrage et al. (2005) observed that some homoionic pure montmorillonites had no water adsorbed ( $0 \mathrm{~W}$ ) at $0 \% \mathrm{RH}$ (in the case of $\mathrm{Na}$ ), whereas others (with $\mathrm{Ca}$ and $\mathrm{Mg}$ ) could have some proportion of $1 \mathrm{~W}$ adsorbed water and, to a lesser extent, $2 \mathrm{~W}$. It is not so simple to extend these findings to a natural claystone containing only a proportion of mixedlayer smectite illite with a natural pore water containing various dissolved salts. However, as shown in Menaceur et al. (2016), the average platelet thickness (deduced from the mean pore diameter) presents step variations in good agreement with the average number of water layers observed in smectites ( $2 \mathrm{~W}$ hydration with $32 \mathrm{~nm}$ average thickness at suctions of various tens of MPa and $1 \mathrm{~W}$ hydration and $28 \mathrm{~nm}$ thickness at suctions of various hundreds of $\mathrm{MPa}$ ). The further decrease in diameter down to $21 \mathrm{~nm}$ after oven drying suggests that this state could correspond to a $0 \mathrm{~W}$ condition, in agreement with some data of Ferrage et al. (2007). In such conditions, Ferrage (personal communication) considered that the $0 \mathrm{~W}$ hypothesis was reasonable in the COx claystone after $48 \mathrm{~h}$ at $105^{\circ} \mathrm{C}$.
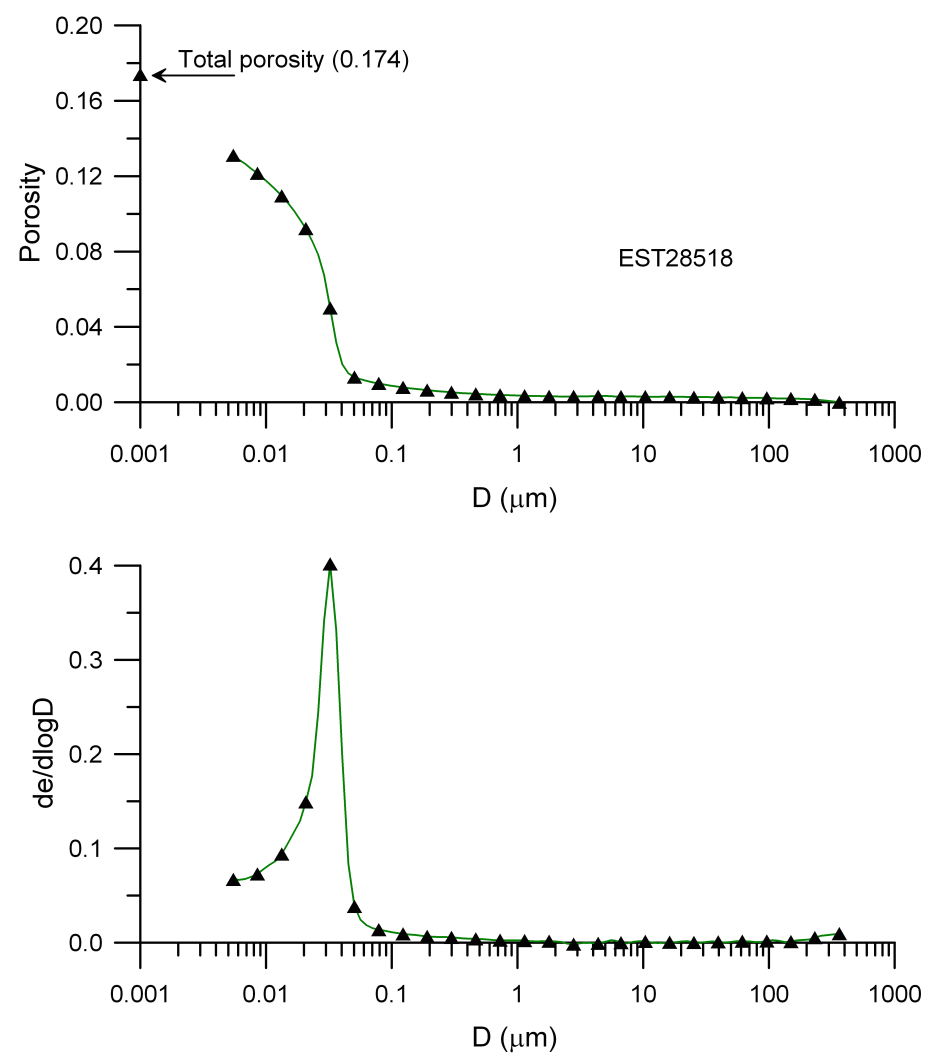

Figure 1. MIP pore size distribution of the COx claystone, after Delage et al. (2014) 
As explained in Menaceur et al. (2016), the free water contained in the COx claystone is that contained in the inter-platelet porosity defined by the MIP curve of Figure 1, and estimated to approximately $75 \%$ of the total porosity. The intra-platelet corresponds to the two layers of water molecules adsorbed along the faces of the smectite layers, within the mixed-layer illitesmectite minerals, corresponding to the remaining $25 \%$.

\subsection{Experimental methods}

The experimental device used for the investigation of the poroelastic properties of the COx claystone, already described in details in Belmokhtar et al. (2016), is presented in Figure 2. It consists in a thermal isotropic compression cell connected to two pressure-volume controllers (PVC, GDS Brand) imposing pressures up to $60 \mathrm{MPa}$. The sample diameter is equal to $38 \mathrm{~mm}$ and a system of axial and radial local strains measurement by mean of LVDTs (Figure 2a) are included in the cell. The short height of the sample $(10 \mathrm{~mm})$ ensure a short drainage length, allows satisfactory saturation within a reasonable period of time and ensure good drainage in drained compression tests (Monfared et al. 2011; Belmokhtar et al. 2016). Drainage is ensured at sample bottom by a thin geotextile. The sample is wrapped in a specially designed cylindrical neoprene membrane able to continuously envelop the top and lateral face of the sample, with no piston or porous disk on the top of the sample. The membrane is tightly fixed to the bottom base by means of two O-rings.

As shown in Figure $2 b$, the cell is immersed in a temperature controlled bath to ensure good temperature control $\left(25^{\circ} \mathrm{C}+/-0.1^{\circ} \mathrm{C}\right.$, measured by means of a thermocouple). Pore pressure changes in the sample are measured by a pressure transducer ( 0 to $75 \mathrm{MPa}$ range) placed outside the bath to avoid any perturbation due to the temperature changes in the bath. One of the two ducts connected to the sample bottom is connected to the pressure transducer 
whereas the other one is connected to the back-pressure PVC, carefully filled by demineralized and de-aired water.

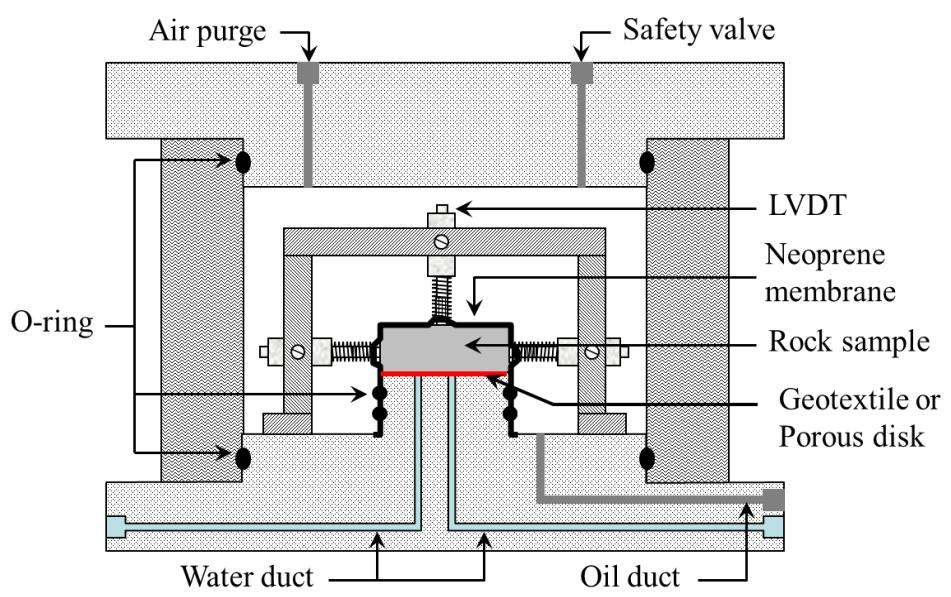

(a)

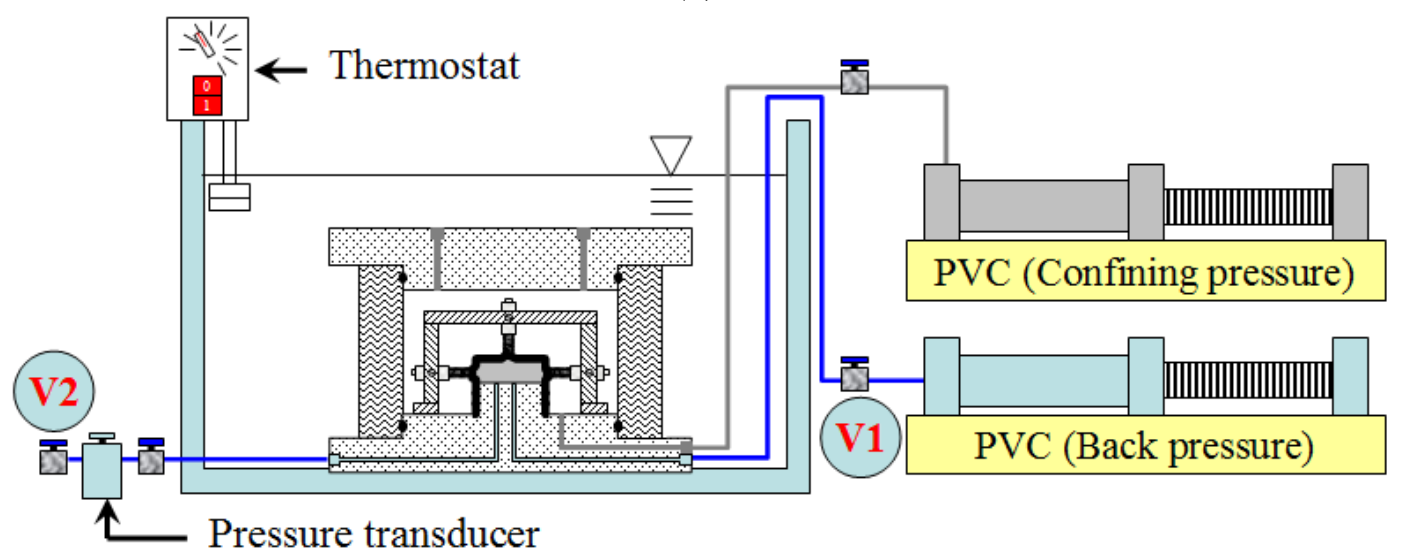

(b)

Figure 2. (a) Isotropic compression cell; (b) Overall system with controlled temperature bath

\subsection{Determination of the Skempton coefficient $B$}

The Skempton $B$ coefficient ( $B=\Delta u / \Delta \sigma$, Skempton 1954) is determined during an undrained compression test as the ratio of the increment of pore pressure $\Delta u$ generated by an increase in confining pressure $\Delta \sigma$. In a poroelastic medium, the expression of $B$ is as follows:

$$
B=\frac{\frac{1}{K_{d}}-\frac{1}{K_{s}}}{\frac{1}{K_{d}}-\frac{1}{K_{s}}+\phi\left(\frac{1}{K_{w}}-\frac{1}{K_{s}}\right)}
$$


where $\phi$ is the porosity, $K_{d}$ is the drained compression modulus of the sample, $K_{s}$ that of the solid phase (determined by running an unjacketed compression test) and $K_{w}$ the compression modulus of water. As commented above, the values of $K_{w}$ and $\phi$ considered in the poroelastic framework are those of the free water contained in the porosity of the sample. This holds in porous rocks in which there is no significant interaction between the solid phase and the pore water, like for instance sandstones. It is no longer true in swelling clay rocks in which the physical properties of a given proportion of water are affected by clay water interactions.

As shown by Wissa (1969), Bishop (1976) and Ghabezloo and Sulem (2010), it is actually not feasible to run a perfectly undrained test by closing the valve of the drainage system, because of the parasite effects induced by unavoidable water transfers between the sample pore water and that of the pore drainage system (porous disk and ducts). Bishop (1976) calculated the correction to make, that was also considered by Monfared et al. (2011a) in a hollow cylinder triaxial apparatus developed to test low permeability clay rocks. The corrected value of the $B$ coefficient is provided in terms of compressibilities (with $c_{i}=1 / K_{i}$ ) as follows:

$$
B^{c o r}=\frac{B^{\text {mes }}}{1+\frac{1}{V\left(c_{d}+c_{s}\right)}\left(V_{p} c_{d p}+V_{g} c_{d g}-B^{m e s}\left(V_{p}\left(c_{d p}+\phi_{p} c_{w}\right)+V_{g} c_{d g}+V_{L}\left(c_{w}+c_{L}\right)\right)\right)}
$$

where $V$ is the volume of the sample, $V_{p}, V_{g}$ and $V_{L}$ are the volumes of the porous disk, geotextile and connecting lines, respectively, and $c_{d p}, c_{d g}$ and $c_{L}$ their drained compressibilities. $\phi_{p}$ is the porosity of the porous disk. $c_{d}, c_{u}$, and $c_{s}$ are the drained, the undrained and the unjacketed compressibilities of the sample, respectively.

Following Monfared et al. (2011a), the drained compressibility of the connecting lines and the drained compressibility of the geotextile in equation (2) were estimated by performing a calibration test on a dummy metal sample and values $c_{L}=0.32 \mathrm{GPa}^{-1}$ and $c_{d g}=9.33 \mathrm{GPa}^{-1}$ were 
obtained for the connecting lines and geotextile, respectively, with $V_{L}=2412 \mathrm{~mm}^{3}$ and $V_{g}=113$ $\mathrm{mm}^{3}$, respectively. The sample volume is $V=11795 \mathrm{~mm}^{3}$.

The drained bulk compressibility and the unjacketed compressibility of the sample were determined by Belmokhtar et al. (2016) and were equal to $c_{d}=0.335 \mathrm{GPa}^{-1}$ and $c_{s}=0.046 \mathrm{GPa}^{-}$ ${ }^{1}$, respectively. The water compressibility at $25^{\circ} \mathrm{C}$ is $\mathrm{c}_{\mathrm{w}}=0.447 \mathrm{GPa}^{-1}$ (Spang, 2002).

\section{Experimental results}

\subsection{Saturation phase}

The first step consisted in loading the sample at constant water initial content under an isotropic confining stress of $8 \mathrm{MPa}$, close to the in-situ mean effective Terzaghi stress. To do so, the sample was set up on a dry cell, with no water inside the ducts and the drainage system, so as to avoid any contact of the sample with water.

The saturation phase was made under a confining pressure equal to the in-situ effective stress so as to minimize swelling during hydration as done by Monfared et al. (2011b) on Opalinus clay and by Mohajerani et al. (2012), Menaceur et al. (2015b) and Belmokhtar et al. (2016) on the COx claystone. Vacuum was applied to the valve close to the pressure transducer (V2 in Figure 2) in order to evacuate the air trapped between the membrane and the sample and in the drainage system. The drainage system under vacuum was then saturated with de-aired water injected from valve V2 while valve V1 was closed. Finally, the confining and pore pressures were simultaneously increased up to $12 \mathrm{MPa}$ and $4 \mathrm{MPa}$ respectively.

Figure 3 shows that the volumetric strains measured by the LVDTs during the saturation phase. They evidence a slight maximum swelling of $0.05 \%$ obtained after $6 \mathrm{~h}$, followed by a subsequent slight decrease and a stabilisation at $0.045 \%$. This limited swelling under hydration is another information on the good quality of the sample that supported little desaturation after coring and trimming, as indicated by a degree of saturation of $94.2 \%$. 


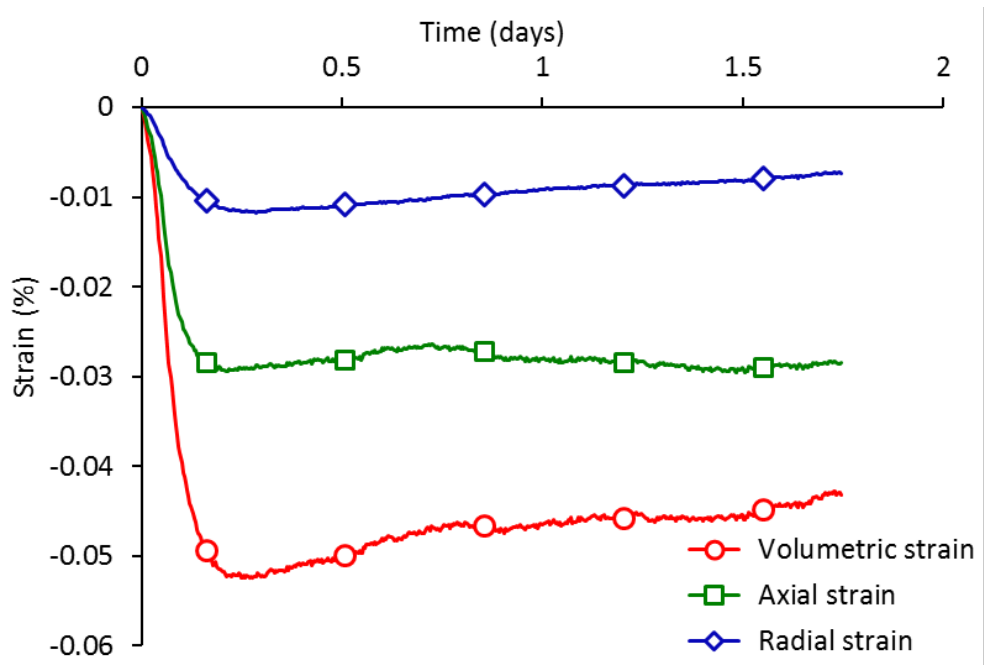

Figure 3. Volume changes during the saturation phase (EST31912-c)

\subsection{Hydromechanical path followed}

The detailed hydromechanical path followed during the test was aimed at determining the poroelastic parameters of the COx claystone. It has been described in details in Belmokhtar et al. (2016) and will not be presented again. Only the relevant experimental data providing the two parameters $K_{d}$ and $K_{s}$ involved in the poroelastic expression of $B$ (Eq. 1) are presented here. The test consisted in:

- A drained isotropic compression test carried between 12 and $14 \mathrm{MPa}$ with the back pressure maintained equal to $4 \mathrm{MPa}$ to bring the specimen at the required initial stress condition $(\sigma=14 \mathrm{MPa}, u=4 \mathrm{MPa})$. The stress rate adopted was equal to $0.5 \mathrm{kPa} / \mathrm{min}$, small enough to ensure satisfactory drainage with the $10 \mathrm{~mm}$ drainage length of the device (see Monfared et al. 2011a and Belmokhtar et al. 2016);

- A drained cyclic loading test (rate $0.5 \mathrm{kPa} / \mathrm{min}$ ) in which the confining stress was decreased to $13.5 \mathrm{MPa}$ and brought back to $14 \mathrm{MPa}$, to determine the elastic drained compression modulus $K_{d}$ around $14 \mathrm{MPa}$, providing a $K_{d}$ value of $2985 \mathrm{MPa}$ (see Figure 4; 
- A test in which the pore pressure was changed between 4 and $4.8 \mathrm{MPa}$ under a constant total stress of $14 \mathrm{MPa}$ to determine the Biot modulus $H$, found equal to $3470 \mathrm{MPa}$;

- An unjacketed compression tests run by changing simultaneously the pore pressure and the confining pressure between 14 and $16 \mathrm{MPa}$, providing a value of $K_{s}$ equal to 21.73 GPa (see Figure 5);

- An undrained isotropic compression test in which the confining pressure was decreased from 13.9 MPa to 12.8 MPa while keeping the valve closed and monitoring the changes in pore pressure to determine the Skempton parameter $B=\Delta u / \Delta \sigma$. This test provided a measured value of $B^{\text {mes }}$ equal to 0.63 (Figure 6).

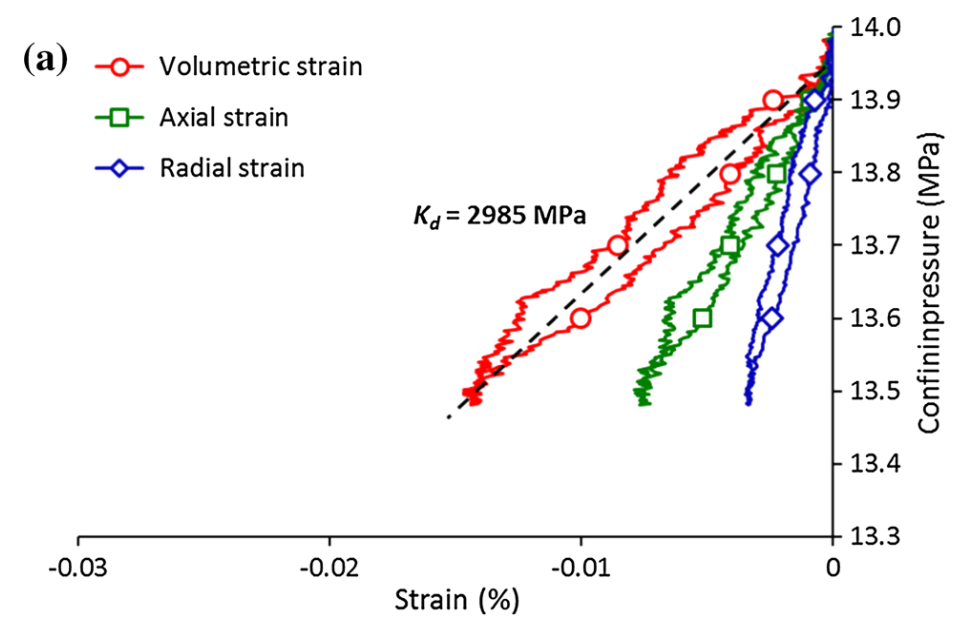

Figure 4. Drained isotropic compression test.

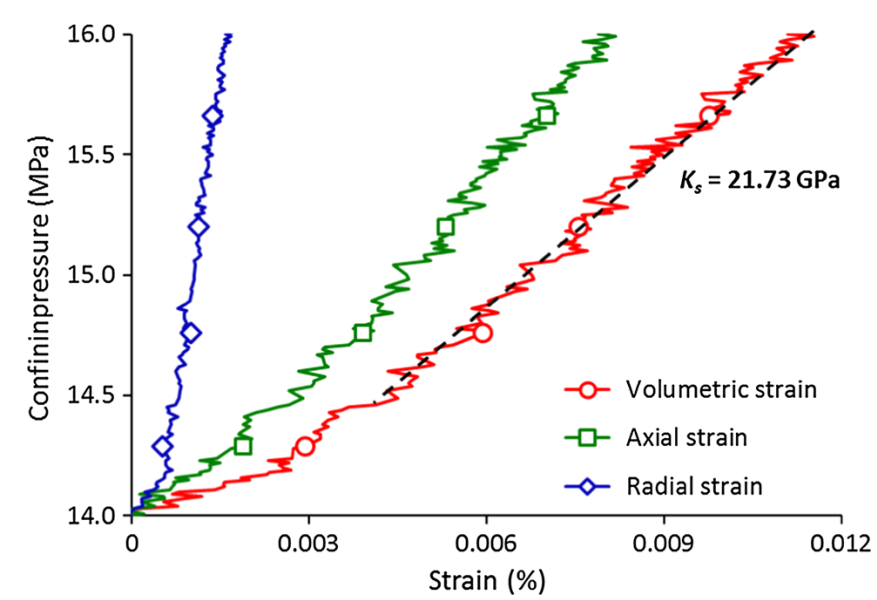

Figure 5. Unjacketed test 


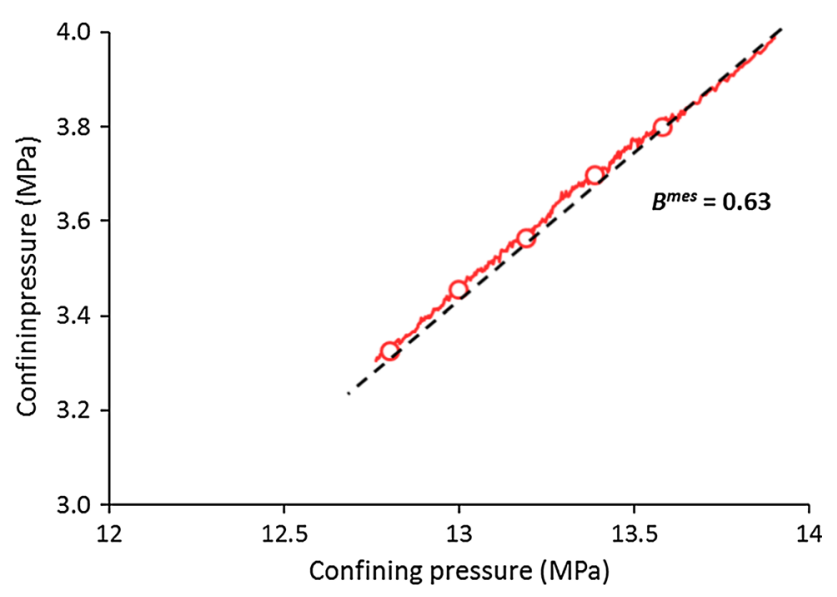

Figure 6. Undrained unloading test

\subsection{The Skempton coefficient}

The corrected value obtained by using to Equation 2 is $B^{c o r}=0.84$, comparable to that obtained on the COx claystone by Mohajerani et al. (2012) during an isotropic compression test performed in a comparable isotropic cell $\left(B^{m e s}=0.7, B^{c o r}=0.85\right)$ and by Mohajerani et al. $(2013)$ in a hollow cylinder cell $\left(B^{\text {mes }}=0.78, B^{c o r}=0.87\right)$. The difference between the measured and corrected values is due to the compressibility and to the dead volume $V_{L}$ of the drainage system, more specifically to the ratio $V_{L} / V$ (where $V$ is the volume of the sample). Compared to Mohajerani et al. (2013), the smaller corrected value obtained in this study is due to the higher $V_{L} / V$ ratio of $20 \%$, resulting in a difference of $25 \%$ between the measured and the corrected value. In Mohajerani et al. (2013), the $V_{L} / V$ ratios were equal to 5\% and 7\%, respectively, resulting in differences of $18 \%$ and $10 \%$, respectively .

\subsection{Active porosity in the COx claystone}

The poroelastic $B$ Skempton parameter depends (Equation 1) on the drained compression modulus of the sample $\left(K_{d}\right)$, and on the compression moduli of both water $\left(K_{w}\right)$ and solid phase $\left(K_{s}\right)$, together with the porosity $\phi$. This relation is valid in porous media in which there is no interaction between water and the solid phase, like for instance in limestones in which a clear distinction can be made between the calcite grains and the water (Lion et al. 2004, Sulem and 
Ouffroukh 2006, Ghabezloo et al. 2009, Hu et al. 2010). The situation is different in claystones, due to the clay-water interactions that affect a proportion of pore water that can no longer be considered as free water. This adsorbed water has been identified in the COx claystone within the framework of the $2 \mathrm{~W}$ hydration of the smectites inside the intra-platelet porosity (Menaceur et al. 2016).

In Table 1, the experimental $B$ values obtained in this study and also in Mohajerani et al. (2013) are compared to that calculated by Equation (1) by using the total sample porosity. The uncertainties on the calculated $B$ values obtained in this work, commented in more details in the Appendix, are also given. The values obtained show that the $B$ values calculated by using the total porosity provide underestimated values, whereas that calculated by using the estimated free porosity of the COx claystone ( $75 \%$ of the total porosity) provides calculated values in good agreement with the measured ones.

Table 1. Effect of total and active porosity on the value of the Skempton coefficient B.

\begin{tabular}{|l|c|c|c|c|c|c|}
\hline \multirow{2}{*}{} & \multirow{2}{*}{$B^{c o r}$} & \multicolumn{2}{|c|}{$\begin{array}{c}\text { Total porosity }\left(\begin{array}{c}\text { Active porosity } \\
\left.\phi_{T}\right)\end{array}\right. \\
\left(\phi_{a c}\right)\end{array}$} & \\
\cline { 3 - 7 } & & $\phi_{T}$ & $B^{\text {calc }}$ & $\phi_{a c}$ & $B^{\text {calc }}$ & Measured $B$ \\
\hline This study & 0.84 & 17.6 & 0.801 & 136 & 0.843 & 0.84 \\
\hline Mohajerani et al. (2013) & 0.87 & 17.7 & 0.838 & 13.28 & 0.873 & 0.87 \\
\hline
\end{tabular}

This conclusion is actually comparable to that of various authors who worked on cement materials. Scherer et al. (2007) argued that a part of the pore fluid in the microstructure of the cement paste was inactive. Like in this work, they evidenced the existence, on the surface of the solid particles, of a layer of immobile water of about $0.5 \mathrm{~nm}$ thickness, also corresponding to two water molecules. Accordingly, they reduced the total porosity of the cement paste for the effect of the thickness of the immobile water. In a similar approach, Sun and Scherer (2010a and b) excluded the volume of interlayer water in their evaluation of the active porosity of mortar samples. Ghabezloo et al. (2008) and Ghabezloo (2010 and 2011) also demonstrated 
that only a proportion of the total porosity of cement, corresponding to the mercury intruded porosity, was to consider when dealing with its poroelastic response. This extension to claystones of findings on other porous material in which mineral/water interactions are also significant confirms the similarity between both materials.

\section{Conclusion}

The mechanical response of swelling claystones and shales is known to be influenced by the clay-water interactions along the faces of the smectite minerals present in their clay fraction. This effect is often accounted for in clay soils and rocks by making a distinction between free water and adsorbed water. In geomechanics, clay water interactions are most often accounted for by using the double diffuse layer theory whereas other important results obtained on the hydration mechanisms in smectites minerals from X-Ray diffractometry techniques are less often considered (e.g. Mooney et al. 1952, Ferrage et al. 2007). As demonstrated by these authors and others, it is now well accepted that the hydration of dry smectites under increased suction occurs by the discrete and successive adsorption of 1,2 and 3 layers of water molecules adsorbed along the faces of the smectite minerals (1W, $2 \mathrm{~W}$ and $3 \mathrm{~W}$ hydration).

The results presented in this work come from the recent contribution of Menaceur et al. (2015), who showed that the nW hydration mechanism was also governing the hydration and swelling response of the Callovo-Oxfordian claystone. They also shown that two layers of water are adsorbed along the smectite faces of the clay fraction at initial state. This allowed to make a distinction between free water, located in the inter-platelets porosity and corresponding approximately to $75 \%$ of the total porosity, and the adsorbed water located inside the platelets along the smectite faces ( $25 \%$ of the total porosity). This work is also based on the work of Belmokhtar et al. (2016) who determined the full set of poroelastic parameters of the COx claystone. 
By comparing the theoretical poroelastic value of the Skempton parameter $B$ to the experimental one obtained from an undrained isotropic compression test, it was shown that the use of the total porosity tended to under-estimate the Skempton parameter. Conversely, considering the inter-platelets porosity determined by mercury intrusion provided compatible values of $B$. This feature was also demonstrated on the data from the tests carried out on the COx claystone by Mohajerani et al. (2013). Interestingly, this conclusion is compatible with that drawn on cement pastes by Scherer et al. (2007) and Sun and Scherer (2010a and b). Cement materials also are porous materials in which the water/minerals interactions are significant. These findings are expected to bring further insight into the macroscopic consequences of the mineralogical and microstructure features of swelling claystones and shales, evidencing that around $25 \%$ of the pore water in the COx claystone does not physically behave like a liquid within the porous medium. These microstructure considerations have clear effect on the macroscopic poroelastic response of the claystone.

\section{References}

Baldi G, Hueckel T, Pellegrini R (1988) Thermal volume changes of the mineral - water system in low-porosity clay soils. Canadian Geotechnical Journal 25, 807-825.

Belmokhtar M, Delage P, Ghabezloo S, Tang AM and Conil N (2016) Poroelasticity of the Callovo-Oxfordian claystone. Rock Mechanics and Rock Engineering, doi:10.1007/s00603-016-1137-3

Bemer E, Longuemare P, Vincké O (2004) Poroelastic parameters of Meuse/Haute Marne argillites: effect of loading and saturation states. Applied Clay Science 26:359-366

Bérend I, Cases JM, François M, Uriot JP, Michot LJ, Masion A, Thomas F (1995) Mechanism of adsorption and desorption of water vapour by homoionic montmorillonites: 2 . The $\mathrm{Li}^{+}$, $\mathrm{Na}^{+}, \mathrm{K}^{+}, \mathrm{Rb}^{+}$and $\mathrm{Cs}^{+}$exchanged forms. Clays and Clay Minerals 43:324-336

Bishop AW (1976) The influence of system compressibility on the observed pore-pressure response to an undrained change in stress in saturated rock. Géotechnique 26:371-375.

Bolt GH, (1956) Physico-chemical analysis of the compressibility of pure clays. Géotechnique $6(2), 86-93$.

Caillère S, Hénin S and Rautureau M 1982. Minéralogie des argiles. I. Structure et propriétés physico-chimiques, 2ème édition, Masson, 184 p, Paris.

Cases JM, Berend I, Besson G, François M, Uriot JP, Thomas F, and Poirier JP (1992) Mechanism of adsorption-desorption of water vapor by homoionic montmorillonite. 1 . The sodium exchanged form. Langmuir, 8, 2730-2739 
Cases JM, Bérend I, François M, Uriot JP, Michot LJ, Thomas F (1997) Mechanism of adsorption and desorption of water vapour by homoionic montmorillonite: 3 . The $\mathrm{Mg}^{2+}$, $\mathrm{Ca}^{2+}, \mathrm{Sr}^{2+}$ and $\mathrm{Ba}^{2+}$ exchanged forms. Clays and Clay Minerals 45:8-22

Escoffier S (2002) Caractérisation expérimentale du comportement hydromécanique des argilites de Meuse Haute-Marne. Ph.D. thesis, Institut National Polytechnique de Lorraine.

Escoffier S, Homand F, Giraud A, Hoteit N and Su K (2005) Under stress permeability determination of the Meuse/Haute-Marne mudstone. Engineering Geology 81(3):329-40.

Davy C, Skoczylas F, Barnichon JD, Lebon P (2007) Permeability of macro-cracked argillite under confinement: Gas and water testing. Physics and Chemistry of the Earth, Parts A/B/C 32:667-680

Delage P, Marcial D, Cui YJ, Ruiz X (2006) Ageing effects in a compacted bentonite: a microstructure approach. Géotechnique 56:291-304.

Delage P, Menaceur H, Tang A-M, Talandier J (2014) Suction effects in deep CallovoOxfordian claystone Suction effects in deep Callovo-Oxfordian claystone. Géotechnique Letters 4:267-271.

Ferrage E, Lanson B, Sakharov BA, Drits VA (2005) Investigation of smectite hydration properties by modeling experimental X-ray diffraction patterns: part I. Montmorillonite hydration properties. American Mineralogist 90:1358-1374

Ferrage E, Kirk CA, Cressey G, Cuadros J (2007) Dehydration of Ca-montmorillonite at the crystal scale. Part I: Structure evolution. American Mineralogist 92:994-1006.

Gaucher E, Robelin C, Matray JM, et al (2004) ANDRA underground research laboratory: Interpretation of the mineralogical and geochemical data acquired in the CallovianOxfordian formation by investigative drilling. Physics and Chemistry of the Earth 29:5577.

Gens, A, Vaunat, J, Garitte, B and Wileveau, Y (2007) In situ behaviour of a stiff layered clay subject to thermal loading: observations and interpretation. Géotechnique 57, No. 2, $207-$ 228

Ghabezloo S, Sulem J, Guédon S, et al (2008) Poromechanical behaviour of hardened cement paste under isotropic loading. Cement and Concrete Research 38:1424-1437.

Ghabezloo S (2010) Association of macroscopic laboratory testing and micromechanics modelling for the evaluation of the poroelastic parameters of a hardened cement paste. Cement and Concrete Research 40:1197-1210.

Ghabezloo S, Sulem J (2010) Effect of the volume of the drainage system on the measurement of undrained thermo-poro-elastic parameters. International Journal of Rock Mechanics and Mining Science 47:60-68.

Ghabezloo S (2011) Micromechanics analysis of thermal expansion and thermal pressurization of a hardened cement paste. Cement and Concrete Research 41:520-532.

Ghabezloo S, Sulem J, Guédon S, Martineau F (2009) Effective stress law for the permeability of a limestone. International Journal of Rock Mechanics and Mining Science 46:297-306.

Homand F, Giraud A, Escoffier S, Koriche A, Hoxha D. (2004) Permeability determination of a deep argillite in saturated and partially saturated conditions. International Journal of Heat and Mass Transfer 47(14-16):3517-3531. 
$\mathrm{Hu}$ DW, Zhou H, Zhang F, Shao JF (2010) Evolution of poroelastic properties and permeability in damaged sandstone. International Journal of Rock Mechanics and Mining Science 47(6):962-973.

Keller LM, Holzer L, Wepf R, Gasser P, Münch B, Marschall P (2011) On the application of focused ion beam nanotomography in characterizing the 3D pore space geometry of Opalinus clay. Physics and Chemistry of the Earth 36:1539-1544

Keller L (2017) Porosity anisotropy of Opalinus Clay: Implications for the poroelastic behavior. Geophysical Journal International, 208 (3): 1443-1448.

Lion M, Skoczylas F, Ledésert B. (2004) Determination of the main hydraulic and poro-elastic properties of a limestone from Bourgogne, France. International Journal of Rock Mechanics and Mining Science 41(6):915-925.

Menaceur H, Delage P, Tang A-M, Conil N (2015a) On the Thermo-Hydro-Mechanical Behaviour of a Sheared Callovo-Oxfordian Claystone Sample with Respect to the EDZ Behaviour. Rock Mechanics and Rock Engineering 6-8.

Menaceur H, Delage P, Tang A-M, Conil N (2015b) The thermo-mechanical behaviour of the Callovo-Oxfordian claystone. International Journal of Rock Mechanics and Mining Science 78:290-303.

Menaceur H, Delage P, Tang AM, Talandier J (2016) The Status of Water in Swelling Shales: An Insight from the Water Retention Properties of the Callovo-Oxfordian Claystone. Rock Mechanics and Rock Engineering. doi: 10.1007/s00603-016-1065-2

Méring J, Glaeser R (1954) Sur le rôle de la valence des cations échangeables dans la montmorillonite. Bulletin de la Société Française de Minéralogie et Cristallographie, $77: 519-530$

Mohajerani M, Delage P, Monfared M, et al (2011) Oedometric compression and swelling behaviour of the Callovo-Oxfordian argillite. International Journal of Rock Mechanics and Mining Science 48:606-615.

Mohajerani M, Delage P, Sulem J, et al (2012) A laboratory investigation of thermally induced pore pressures in the Callovo-Oxfordian claystone. International Journal of Rock Mechanics and Mining Science 52:112-121.

Mohajerani M, Delage P, Sulem J, et al (2013) The Thermal Volume Changes of the CallovoOxfordian Claystone. Rock Mechanics and Rock Engineering 47:131-142.

Monfared M, Delage P, Sulem J, et al (2011a) A new hollow cylinder triaxial cell to study the behavior of geo-materials with low permeability. International Journal of Rock Mechanics and Mining Science 48:637-649.

Monfared M, Sulem J, Delage P, Mohajerani M (2011b) A Laboratory Investigation on Thermal Properties of the Opalinus Claystone. Rock Mechanics and Rock Engineering 44:735747.

Mooney RW, Keenan AG, Wood LA (1952) Adsorption of Water Vapor by Montmorillonite. II. Effect of Exchangeable Ions and Lattice Swelling as Measured by X-Ray Diffraction. Journal of the American Chemical Society 74:1371-1374.

Noiret A, Giot R, Bemer E, Giraud A, and Homand F (2010) Hydromechanical behavior of Tournemire argillites: Measurement of the poroelastic parameters and estimation of the intrinsic permeability by œdometric tests. International Journal for Numerical and Analytical Methods in Geomechanics 35: 496-518 
Norrish K (1954) The swelling of montmorillonite. Discussion, Faraday Society 18:120-133

Robinet J.C., Sardini P., Siitari-Kauppi M., Prêt D. and Yven B. 2015. Upscaling the porosity of the Callovo-Oxfordian mudstone from the pore scale to the formation scale; insights from the 3H-PMMA autoradiography technique and SEM BSE imaging. Sedimentary Geology 321 (2015) 1-10

Saiyouri N, Hicher PY, Tessier D (2000) Microstructural approach and transfer water modelling in highly compacted unsaturated swelling clays. Mech Cohesive-Frictional Mater 5:41-60.

Saiyouri N, Tessier D, Hicher PY (2004) Experimental study of swelling in unsaturated compacted clays. Clay Minerals 39:469-479.

Schanz T, Tripathy S (2009) Swelling pressure of a divalent-rich bentonite: diffuse doublelayer theory revisited. Water Resources Research 45 (2)

Scherer GW, Valenza II JJ, Simmons G (2007) New methods to measure liquid permeability in porous materials, Cement and Concrete Research 37 386-397.

Skempton, A. W. (1954) The Pore Pressure Coefficients A and B. Géotechnique, 4: 143-147.

Spang B. (2002) Excel Add-In for Properties of Water and Steam in SIUnits;http://www.cheresources.com/staff.shtml.

Sridharan A, Jayadeva MS (1982) Double layer theory and compressibility of clays. Géotechnique 32 (2), 133-144.

Sun Z, Scherer GW (2010a), Effect of air voids on salt scaling an internal freezing, Cement and Concrete Research 40 (2) 260-270.

Sun Z, Scherer GW (2010b) Pore size and shape in mortar by thermoporometry, Cement and Concrete Research, 40, 740-751.

Sulem J, Ouffroukh H (2006) Hydromechanical Behaviour of Fontainebleau Sandstone. Rock Mechanics and Rock Engineering 39:185-213.

Tessier D, Dardaine M, Beaulont A, Jaunet M (1998) Swelling Pressure and Microstructure of an Activated Swelling Clay with Temperature. Clay Minerals 33:255-267.

Vincké O, Longuemare P, Boutéca M, Deflandre J-P (1998) Investigation of the poromechanical behavior of shales in the elastic domain. Paper SPE 47589:1-6.

Wileveau Y, Cornet FH, Desroches J, Blumling P (2007) Complete in situ stress determination in an argillite sedimentary formation. Physics and Chemistry of the Earth 32:866-878.

Wissa AEZ (1969) Pore pressure measurement in saturated stiff soils. Journal of the Soil Mechanics and Foundations Division 95(4):1063-1074.

Yang S., Davy C.A., Troadec D., Blanchenet A.-M., Skoczylas F., Talandier J., Robinet J.C. (2015) Multi-scale pore structure of COx claystone: Towards the prediction of fluid transport. Marine and Petroleum Geology 65:63-82.

Yven B, Sammartino S, Geraud Y, et al (2007) Mineralogy, texture and porosity of CallovoOxfordian argilites of the Meuse/Haute-Marne region (eastern Paris Basin). Mémoires la Société Géologique de France 0249-7546:73-90.

Yuan H, Agostini Fb, Duana Z, Skoczylas F and Talandier J (2017) Measurement of Biot's coefficient for COx argillite using gas pressure technique. International Journal of Rock Mechanics and Mining Sciences 92:72-80. 
Zhang CL, Rothfuchs T (2008) Damage and sealing of clay rocks detected by measurements of gas permeability. Physics and Chemistry of the Earth, Parts A/B/C 33:S363-S373.

\section{Appendix: Uncertainty calculations}

The determination of the uncertainties on the calculated $B$ values of Table 1 was made considering the following uncertainties adopted for each parameter of Eq. (1).

The uncertainties in $K_{d}$ and $K_{s}$ were calculated based on the uncertainties in stress given by the PVC manufacturer (GDS, $\pm 0.02 \mathrm{MPa}$ ), on the uncertainty in the determination of the initial size of the specimen $( \pm 0.01 \mathrm{~mm}$ with the precision calliper $)$ and on that in the displacement measurement with LVDTs $( \pm 0.1 \mu \mathrm{m})$. Uncertainties calculations provided values of $\pm 0.5 \mathrm{GPa}$ for $K_{d}$ and $\pm 5.1 \mathrm{GPa}$ for $K_{s}$. The value of water compression modulus was taken from Spang (2002), with an uncertainty estimated at $\pm 0.02 \mathrm{GPa}$.

The uncertainty in porosity was calculated by considering the determination of the volume of the pieces of claystone by hydraulic weighing, carried out by using a scale with $0.001 \mathrm{~g}$ precision, resulting in a $0.001 \mathrm{~g}$ uncertainty in the measurement of the total mass, the dry mass and the apparent mass of the material immersed in oil. The uncertainties in grain density was estimated by Andra (2005) from running several measurements at $\pm 0.02 \mathrm{~kg} / \mathrm{m}^{3}$. The uncertainty in oil density determined in the laboratory by pycnometer measurement was estimated at $\pm 0.0001 \mathrm{~kg} / \mathrm{m}^{3}$ and considered negligible. These uncertainties result in an uncertainty of $\pm 0.003 \mathrm{~cm}^{3}$ in the volume measurement, giving an uncertainty of $\pm 0.7 \%$ for the total porosity and $\pm 0.5 \%$ for the active porosity (estimated at $75 \%$ of the total porosity).

The overall measured parameters and their corresponding uncertainties are resumed in Table 2 together with that estimated for the Skempton parameters calculated from the total porosity $( \pm 0.040)$ and from the active porosity $( \pm 0.033)$. 
Table 2. Uncertainty calculations.

\begin{tabular}{lcl}
\hline Parameter & Measured/calculated value & Uncertainty \\
\hline$K_{d}(\mathrm{GPa})$ & 2.98 & \pm 0.5 \\
$K_{w}(\mathrm{GPa})$ & 2.24 & \pm 0.02 \\
$K_{s}(\mathrm{GPa})$ & 21.73 & \pm 5.1 \\
Total porosity $\phi_{T}(\%)$ & 17.6 & \pm 0.7 \\
Calculated $B$ with $\phi_{T}(-)$ & 0.804 & \pm 0.040 \\
Active porosity $\phi_{a c}(\%)$ & 13.2 & \pm 0.5 \\
Calculated $B$ with $\phi_{a c}(-)$ & 0.843 & \pm 0.033 \\
\hline
\end{tabular}

